\title{
Strengths, Weakness, Opportunities and Threats of Indigenous Library and Information Science Education in Distance Mode
}

\author{
Sambhu Nath Halder
}

\begin{abstract}
This paper presents the current scenario of library and information science (LIS) education in India, with special reference to open and distance mode. In the centenary year of LIS education in India, it is important to evaluate the existing system. SWOT analysis is a tool to evaluate the Strengths, Weakness, Opportunities and Threats of Indigenous LIS education in distance mode. The analysis is carried out in the light of national-level practices and perspective. Analysis of SWOT results in few strategies, which can be useful for contemporary open and distance education centres in India.

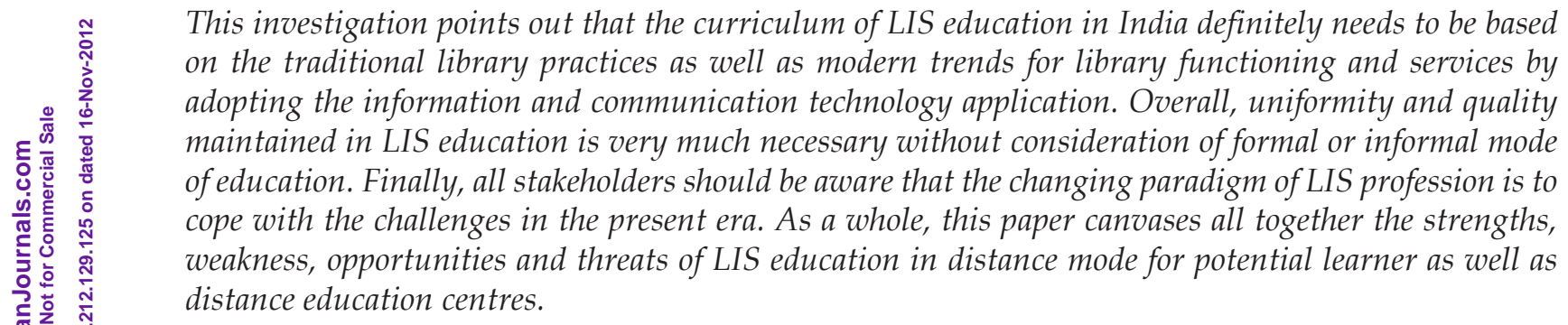

Keywords: Distance education, LIS education, SWOT analysis

\section{INTRODUCTION}

Last year was the centenary year of Library 髜d Information Science (LIS) education in India. In the context of LIS education, Sarkhel (2006) highlighted that W.A. Borden, Librarian of Young Man's Institute, New Haven, Connecticut, USA started the first training programme for library workers at the Central Library in Baroda in 1911. In 1915, Asa Don Dickinson, another American Librarian, established a training course in erstwhile Punjab University (now in Pakistan), which is considered to be the second library school in the world, the first being the Columbia School. Both Borden and Dickinson, who paved the way for LIS education in India, were the students of Melvil Dewey. Later, the outstanding contributions of Dr. S.R. Ranganathan gave a new impetus to the spread of LIS education at the university level in India. LIS education in India has expanded since independence in the form of increase in number of LIS departments in the universities and institutions offering specialised courses in LIS, and in the increase in number of students as well as courses. Research has also been initiated and accelerated in different facets of the subject, with the support of the universities and different funding agencies (Satija, 1993).

Beyond the conventional regular courses of learning, distance learning system (DLS) gives access to wide range of people who have some difficulties to attend classroom learning. DLS gives wider access to higher education to persons of all ages and sex residing anywhere in the nation, especially to persons in-service, those who could not undergo higher education at regular conventional system for different reasons. It 


\section{Sambhu Nath Halder}

provides a system of student-centred self-paced learning, which provides opportunity for the improvement of professional skills and competence of individuals who enjoy taking education as life-long learning. Finally, it ensures, as far as feasible, appropriate value addition to career prospects in prevailing market opportunities.

\section{LIS EDUCATION IN DISTANCE MODE}

Distance education system could be defined in different ways. According to online dictionary of LIS, distance learning is a method of instruction and learning designed to overcome barriers of time and space by allowing students to study in their own homes or at local facilities, often at their own convenience, using materials available edectronically or by mail. Communication with the

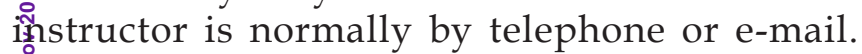
Eelecommunication networks and teleconferecing have facilitated distance learning. Libraries are working to support distance learning by roviding online catalogs and databases, ectronic reserves, electronic reference service, (⿳亠丷⿵冂丶 siervice (Reitz, 2004).

Distance education is the "education program thereby students may complete all or part of an क्षdducational program in a geographical location 함 the final award given is equivalent in standard and content to an award program completed on campus" (Newsweek Distance Learning, 2005).

Open and distance education systems have started internet-based online methods, which offer more sophisticated online education by using intelligent multimedia online, Internet-based access to web resources, computer-mediated communication using automated response systems and campus portal access to institutional processes and resources.

\section{SALIENT FEATURES OF DISTANCE EDUCATION}

The system of classroom education that has been established for centuries has recently undergone great changes, many of which were provoked by the growing demands of a population requiring increased cultural and professional training, but which for various reasons, like the distance, work and cost etc., cannot be met by traditional courses. New distance courses are offered somewhat frequently, but, in general, the public considers distance education as a second choice or supplementary to conventional education. There are some points to highlight that the distance education system has acquired:

- Distance education is a predominantly learnercentred system that supports independent learning, primarily based on course material in self-learning format.

- Teacher and student are separated by distance and time.

- Technology tools are used for communication, delivery, collaboration and cost containment.

- Opportunity for more students to receive quality education.

- Flexible educational system that is not limited by age, time and place restrictions.

- It can supplement the studies of regular students along with being a separate system of education.

- This system facilitates learner to progress at his own speed.

- It is an ideal system to fulfill the need of those learner(s) who fall out of the conventional stream for different reasons.

- This system could reach any remote area through postal service if not through television.

- It leads to self-learning, which is education in the real sense and stable and also which is not really encouraged in most of teaching institutions.

\section{PROGRESS OF DISTANCE EDUCATION IN INDIA}

As the formal system was unable to meet the demand for higher education in India, the planning commission in its third 5-year plan (1961-1966) recommended the introduction of 
distance education at the university level. The period 1962 to early 1980s was the correspondence education phase. The 1970s saw a spurt in the growth of correspondence education. The 1980s and 1990s are referred to as the open university phase. Dr. B.R. Ambedkar Open University, Hyderabad (then known as Andhra Pradesh Open University) was the first open university in India offering LIS programmes through correspondence at Bachelor's Degree and Master's Degree, from 1985 and 1998, respectively, followed by the University of Madras. Indira Gandhi National Open University (IGNOU) was established by an Act of Parliament in 1985. It started Bachelor in Library and Information Science BLISc in 1989 and later Master in Library and Information Science (MLISc) and Ph.D. rrogrammes. The growth of distance education Grogrammes in India has created an outbreak in

xpansion affected the professional calibre and the quality of education being imparted. The latter part of the 1990s saw the beginning of the virtual education phase when online courses were iñ

Nowadays, the following LIS courses are Efffered by various open and distance education 萧stitutions in India:

Certificate course in LIS (CLIS).

- Diploma in LIS (DLIS).

- B.Lib.Sc./BLIS (Bachelor Degree in LIS).

- M.Lib.Sc./MLIS (Master Degree in LIS).

- PGDLAN (Post-Graduate Diploma in Library Automation and Networking).

- M. Phil. (Master of Philosophy) in LIS.

- Ph.D. (Doctor of Philosophy) in LIS.

A list of institutions offering various courses in LIS under distance mode in India is given bellow:

\section{SWOT ANALYSIS OF LIS LEARNING IN DISTANCE EDUCATION}

SWOT analysis is a tool that identifies the strengths, weaknesses, opportunities and threats of an organisation. The method of SWOT analysis is to take the information from an environmental analysis and separate it into internal (strengths and weaknesses) and external issues (opportunities and threats). Once SWOT is completed, this determines what may aid the firm in achieving its objectives, and what obstacles must be overcome or minimised to achieve the desired results. According to Wikipedia: the free encyclopedia (2011), SWOT analysis is a strategic planning method used to evaluate the strengths, weaknesses, opportunities and threats involved in a project or in a business venture. It involves specifying the objective of the business venture or project and identifying the internal and external factors that are favourable and unfavourable in achieving that objective. Earlier, Deshpande and Ashtikar (2005) have done the SWOT analysis of distance education, but it was completed rather in a general way. Now, with the help of SWOT analysis, the entire LIS education system in distance mode is evaluated properly.

\subsection{Strengths}

Nowadays, LIS education in distance mode is becoming popular gradually. This system opens the door for those learners who have difficulties to enter conventional education in LIS. In this regard, the strengths side of the said system is highlighted here:

- Large number of youth population waiting to go for higher education, but are not able to attend regular classes, due to many causes, like person in-service, living in remote places, etc., will be able to pursue higher education.

- Low cost of the education within the reach of rural people and financially handicapped students. Side by side, in university point of view, expenditure on account of salaries is also less than the conventional system.

- Requisite individual learning opportunities, like self-learning materials (SLMs), personal contact programme, etc., are provided by the DLS.

- Abundance of technology and cyber culture 


\section{Sambhu Nath Halder}

Table 1: LIS education in India under open/distance mode

\begin{tabular}{|c|c|c|c|c|c|c|c|}
\hline S.No. & State & Name of open/distance education institution & BLIS & MLIS & M. Phil. & Ph.D. & Others \\
\hline 1. & Andhra Pradesh & Dr. B.R. Ambedkar Open University [1982] & Yes & Yes & No & No & No \\
\hline 2. & Andhra Pradesh & Kakatiya University [1976] & Yes & No & No & No & No \\
\hline 3. & Andhra Pradesh & Sri Venkateswara University [1954] & Yes & No & No & No & No \\
\hline 4. & Andhra Pradesh & Andhra University [1926] & No & Yes & No & No & No \\
\hline 5. & Bihar & Nalanda Open University [1995] & Yes & Yes & No & No & No \\
\hline 6. & Bihar & Lalit Narayan Mithila University [1972] & Yes & Yes & No & No & No \\
\hline 7. & Bihar & Patna University [1917] & Yes & No & No & No & No \\
\hline 8. & Haryana & Kurukshetra University [1956] & Yes & Yes & No & No & No \\
\hline 9. & Kerala & University of Calicut [1968] & Yes & No & No & No & No \\
\hline 10. & Madhya Pradesh & Awadesh Pratap Singh University [1968] & Yes & No & No & No & No \\
\hline 11. & Madhya Pradesh & Barkatullah University [1970] & Yes & Yes & No & No & No \\
\hline 12. & Madhya Pradesh & Dr. Hari Singh Gour Vishwavidyalaya [1946] & Yes & Yes & No & No & No \\
\hline 13. & Madhya Pradesh & Guru Ghasidas University [1983] & Yes & Yes & No & No & No \\
\hline 14. & Madhya Pradesh & Mahatma Gandhi Gramodaya Vishwavidyalaya [1991] & Yes & Yes & No & No & No \\
\hline 15. & Maharashtra & Yashwant Rao Chavan Maharashtra Open University [1990] & Yes & No & No & No & No \\
\hline 16. & New Delhi & Indira Gandhi National Open University [1985] & Yes & Yes & No & No & PGDLAN \\
\hline 率 7. & Rajasthan & Kota Open University [1987] & No & No & No & No & $\begin{array}{l}\text { Diploma } \\
\text { in LIS }\end{array}$ \\
\hline E. & Tamil Nadu & $\begin{array}{l}\text { Vinayaka Missions University, Directorate of Distance } \\
\text { Education [2005] }\end{array}$ & Yes & Yes & Yes & No & $\begin{array}{l}\text { Certificate } \\
\text { in LIS }\end{array}$ \\
\hline ن⿺辶. & Tamil Nadu & Alagappa University [1985] & Yes & No & No & No & No \\
\hline 筮0. & Tamil Nadu & Annamalai University [1929] & Yes & Yes & No & No & No \\
\hline क्षें1. & Tamil Nadu & Bharathidasan University [1982] & Yes & No & No & No & No \\
\hline 芘 & Tamil Nadu & Madurai Kamraj University [1965] & Yes & Yes & No & No & No \\
\hline 管3. & Tamil Nadu & Madras University [1857] & Yes & Yes & No & No & No \\
\hline 24 & Uttar Pradesh & U.P. Rajarshi Tandon Open University [2004] & Yes & No & No & No & No \\
\hline 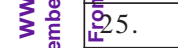 & West Bengal & Netaji Subhas Open University [1997] & Yes & Yes & No & Yes & No \\
\hline 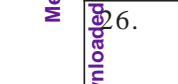 & West Bengal & $\begin{array}{l}\text { University of Kalyani, Directorate of Open \& Distance } \\
\text { Learning [1960] }\end{array}$ & No & No & Yes & No & No \\
\hline
\end{tabular}

\&ote: All open/distance education institutions are arranged alphabetically under their respective states. The date of Gazette Notification regarding establishment of the universities is given within square brackets immediately after name of open/distance education institution. Yes or No indicates whether the institution offers the degree or not.

makes the DLS more sophisticated and easy accessible. Multimedia programmes are also easily understandable, which are provided by some open and distance learning institutions.

- Besides the SLMs, library facilities are also provided to all distance learners. Provisions for acquisition of books and journals - both print and digital and educational Compact Discs (CDs), Video Compact Disks (VCDs) and Digital Video Discs DVDs falling within the purview of the subjects offered by the university under distance mode.

- There is no restriction of physical boundary, so any eligible person from anywhere can pursue the required course.
- With the help of Internet, more programmes become effective (online communication and feedback) and systematic, where anyone would be able to reach host website from remote place within least possible time.

- Programmes are recognised by national-level apex bodies like the University Grants Commission (UGC) and the All India Council for Technical Education (AICTE), hence no fear of recognisation of the course.

- It is more economical as compared with the conventional programmes, for students as well as for organisations.

- More mature students, even some of them are 
employed in government or non-government institutions. So, practical experience can help them catch the knowledge in the concerned field.

- There is huge opportunity of useful interaction with the industries or world of work through employed students.

- There is no need to establish their own laboratory and appoint the teaching faculty members for practical class.

Besides these, The Department of Education, Ministry of Human Resources Development, Government of India has notified vide the Notification No. 44, dated 01-03-1995, published on Saturday, 8 April 1995 in the Gazette of India that "on the recommendation of the Board of Assessment for Educational Qualification, the Sovernment of India has decided that all the Thalifications awarded through Distance Education or State Legislature, Institutions Deemed to be \&niversities under Section 3 of the UGC Act, 1956 离d Institutions of National Importance declared under 衆 Act of Parliament stand automatically recognised for the purpose of employment to posts and services ander the Central Government, provided it has been 禀proved by Distance Education Council." With all advantages discussed above, distance education 章stem has established the field, where increasing ITิumbers of candidates are enrolled every year.

\subsection{Weakness}

The ultimate aim of any professional course like LIS is to make job seekers enrolled in the system employable and marketable. The universities that have correspondence courses in LIS are not producing such candidates who have the adequate skills. A close examination of the past studies (Mangla, 1998; Singh, 2003) reveals that there are lots of problems that confront the LIS education in India. A brief description of the weakness wings of LIS education in distance mode are enumerated below:

- Investment by Distance Education Centres: Finance is a major issue. Without appropriate financial support, it is not possible to make any resource available. The agencies issuing grants like the UGC, university authorities and other bodies do not support LIS schools needing special grants for infrastructure, faculty and other necessary items.

- Practical and Real-Field Hands on Experiences: Because of professional education, LIS needs some practical and real-field hands on experience to fit different types of work environment. Most of the distance education study centres conducting LIS education are not equipped with well-furnished computer laboratory and library facilities, communication equipments and other information science components that are required for LIS departments.

One of the main constraints of e-learning systems is that students need to know how to use a particular information technology. Much more attention will be required in future web-based training that will be delivered over the internet using the non-propriety www server and client technology. Despite the increase in the number of institutions offering distance programmes, little is known about the teaching practices that contribute to effective online course design and delivery.

- Teacher-Student Interaction: Being a practicaloriented course, LIS education requires computer training and practical classes for classification and cataloguing with personal contact between teacher and student; but the numbers of days for contact classes are very limited. Some universities do not even insist on students to attend contact classes. There is no provision of credit hours for individual papers in the distance programme.

- Adequate Infrastructure: Space is one of the important requisites to create sound learning environment. Library facility is also a vital organ of any educational system. In distance education system, all these factors are not always maintained properly. Besides this, it lacks full-time faculty members and the teaching aids also. 


\section{Sambhu Nath Halder}

- Uniformity: There are no standard rules and regulations in the national level regarding selection criteria for admission, intake, class hours, teaching methodology, distribution of marks, methods of evaluation and research programmes in distance education system. So, it lacks uniformity.

- Curricula and Duration of LIS Courses: Curricula of BLISc and MLISc are not uniform in LIS schools; very little emphasis is given to the components that the LIS professionals need to carry out on the tasks in the library when they join the given job. However, one of the problems with e-learning in India is the lack of course content, especially outside the mainstream focus areas of Information Technology (IT) education, English-language content and tutorial-like courses. There will be a high demand for people who can develop multilingual courseware that addresses various topics. The course duration at each level is also not uniform in the LIS schools. The correspondence courses had made their own style of nomenclature, curricula and duration.

In addition to mastering new and inter⿷匚isciplinary subject areas, this required the (⿻木口)evelopment of a facility for the flexible delivery off courses in distance mode (Martin, 1999). In the 辣ue sense, the weakness may be turned into opportunities by the careful consideration of the said points.

\subsection{Opportunities}

Distance education is nothing but the process of acquiring knowledge and qualification without attending classroom on regular basis, for those who could not afford normal education due to some difficulties like non-availability of admission, finance, geographical location, suitable time, etc. Sacchanand (1998) opines some opportunities associated with LIS education in distance mode. Significant opportunities are summarised below:

- Distance education system provides the opportunities to acquire or update skills and knowledge in areas increasingly in demand.
- It enhances already acquired professional qualification. Individual subjects may be taken as continuing education courses, without the need to meet formal entry requirements.

- Open and distance education system increases access to education and meets the needs of learners who are already in the workforce. It creates opportunities for people with families and work commitments, who are unable to continue their studies at conventional universities.

- It emphasises freedom from classroom limitations in location and time. Distance education is flexible with variable timings and locations, whether at work or at home. Time to learn is extended to fit individual needs.

- It offers a chance to information professionals and people who live and work in remote areas and have no way of improving and continuing their education.

- Opportunity to enroll youth who are not absorbed in conventional education system of LIS.

- Government supports, hence possibility of getting adequate funds is there.

- Several new curriculum on the backdrop of globalisation.

- Due to development of information and communication technology (ICT) and application of multimedia approach the open and distance education is more effective in terms of curriculum delivery, contact lectures, audio-visual conferencing, etc. So, it is a good opportunity for up-gradation of skills and qualifications.

- Distance education system is highly accessible worldwide. As there are no geographical boundaries, any remote learner can get access.

- Learners in online and distance education system will be able to acquire project organisation image through virtual tools.

- Need-based or tailor-made programme launching creates a good opportunity to new generation people.

In a single word, distance education system 
opens the door for all deserving people to higher learning and grows updated knowledge on their field.

\subsection{Threats}

Besides the opportunities associated with LIS education in distance mode, there are some threats to enroll this system. Threats refer to those things that currently exist within the system and those things that can prevent the organisation from achieving its goal. The major threats are listed here:

- Authenticity of practical skills development may be questioned, although in-service learners have good practical exposure; but some of the freshers face the lacuna of handson practice and to be fit for real-field scenarios.

Technical and vocational product of distance mode may get less preference than contact mode product.

Open and distance universities are affiliated by the apex bodies like the UGC and the AICTE and recognised by the Distance Education Council, Government of India and the regulatory apex body of open and distance learning ODL in India, but, there is no overall acceptance by the industry and the world of work.

Need of getting programme accredited with apex educational or professional bodies like, the National Assessment and Accreditation Council and the National Board of Accreditation.

- The UGC has banned pursuing research programmes like M. Phil. and/or Ph.D. from distance mode from the year 2009. However, the UGC has lifted the ban from IGNOU, New Delhi, for conducting Ph.D. courses in distance mode.

- While imparting practical skills, development of component system will face a lot of odds.

- Mushrooming of non-granted LIS schools.

- Large number of dropouts is another threat to this system. A good number of students are enrolled every year, but they are not completing their course in due time.
The threats are to be converted into the opportunities by entering into the collaborative distance education programmes with such institutes.

\section{CONCLUSION}

Distance learning is gradually seen as an effective alternative means to acquire actionable skills and knowledge. To cope with the changing paradigm, LIS professionals have to possess required knowledge and skill to apply it in realfield situation. Different kinds of libraries in the present era and job market expectations demand modernisation of the teaching and learning pattern of LIS education. Overall uniformity and quality maintenance in LIS education are very much needed without consideration of formal or informal mode of education.

The birth of distance education system and its rapid spread in India and abroad have been possible due to the advancement in ICT. More and more people are now turning to the mode of distance education for widening their knowledge base and for becoming proficient in their work life. Therefore, now there is a need for devising a new digitised system that would act as a facilitator for the distance learners and help them in acquiring timely and relevant qualification. In this regard, organised and focused efforts are needed by various agencies, viz., the Central Government, the State Government, the UGC, the Association of Indian Universities (AIU), University Administration, LIS professionals, teachers and students also. The curriculum of LIS education in India definitely needs to be based on the traditional library practices as well as modern trends for library functioning and services by adapting the ICT application.

Besides, there should be a National Council for Library \& Information Science on the pattern of National Council for Teacher Education (NCTE) formed for maintaining standards in teacher's education, as suggested by Dhiman (2011), to look after all the things related to LIS education. 


\section{Sambhu Nath Halder}

\section{REFERENCES}

1. Deshpande, S.G. and Ashtikar, R. (2005). SWOT Analysis of Distance Education for Testing its Suitability to impart Technical and Vocational Education. Paper presented at ICDE International Conference, New Delhi.

2. Dhiman, A.K. (2011). "Library science education in Uttarakhand: an appraisal", in Singh, J., and Kaur, T. (eds.), LIS Education, Research and Training: Vision 2020", pp. 499509, IATLIS, Patiala.

3. Mangla, P.B. (1998). "Library and information science education: trends and issues", in Jain, M.K. (ed.), Fifty years of Library and Information Services in India, pp. 283-293, Shipra Publications, New Delhi.

4. Martin, W. (1999). "New directions in education for LIS: knowledge management programs at RMIT". Journal of Education for Library and Information Science, 40(3): 142150.

Newsweek Distance Learning. (2005). Distance Education (Learning). Retrieved from: $h$ ttp://faculty.ksu.edu.sa/kheraiji/ Documents/library/golssary.htm.

Reitz, J.M. (2004). Online Dictionary for Library and Information Science. Retrieved on 11 July 2011, from http:// www.abc-clio.com/ODLIS/searchODLIS.aspx.
7. Sacchanand, C. (1998). Distance Education in Library and Information Science in Asia and the Pacific Region. Paper presented at $64^{\text {th }}$ IFLA General Conference, Amsterdam, Netherlands in August 1998.

8. Sarkhel, J.K. (2006). "Quality assurance and accreditation of LIS education in Indian universities: issues and perspectives", in Khoo, C., Singh, D. and Chaudhry A.S. (eds.), Proceedings of the Asia-Pacific Conference on Library $\mathcal{E}$ Information Education \& Practice, pp. 427-431, Nanyang Technological University, Singapore. Retrieved on 11 July 2011, Available at : http://www.coursehero.com/file/1303202/61JuranKrishna Sarkhelpp427-431/.

9. Satija, M.P. (1993). "Researches in librarianship: before and after Ranganathan", in Navalani, K. and Satija, M.P. (eds.), "Pettitis Petals: A Tribute to S.R. Ranganathan", pp. 27-45, ABC Publishing, New Delhi.

10. Singh, S.P. (2003). Are We Really Ready to Face Challenges of the LIS Profession? Paper presented at the $24^{\text {th }}$ All India Conference of IASLIC, Calcutta, pp. 449-456.

11. Wikipedia: the free encyclopedia. (2011). SWOT Analysis. Retrieved on 30 June 2011 from website http:// en.wikipedia.org/wiki/SWOT_analysis. 